\author{
Alexander SCHREK ${ }^{1}$ \\ Pavol ŠVEC ${ }^{2}$ \\ Veronika GAJDOŠOVÁ ${ }^{3}$
}

\title{
DEEP DRAWING OF TAILOR-WELDED BLANKS MADE OF HIGH-STRENGTH STEEL
}

\begin{abstract}
A comparison study was conducted to evaluate the deep drawing of a rectangular box from tailor-welded blank, composed of two parts of different thicknesses. The blank material is high strength steel with transformation induced plasticity, and the weld line is located in the blank centre at the beginning of the deep drawing. The study is focused on the weld line movement during the deep drawing with quasi uniform or controlled non-uniform distribution of the blankholder pressure, which is applied on the flange of the blank. The goal is to minimise the weld line movement and to improve the formability of the tailor-welded blank.
\end{abstract}

Keywords: deep drawing, tailor-welded blank, simulation, weld line

\section{Introduction}

Tailored blanks for deep-drawing, consisting of parts of the same type of material but of a different thickness or of different grades of material are now widely used in the automotive industry for car body and other structures. The main advantages of their use are a reduction of the tools number, decreasing assembly costs, material savings, avoiding spot welding, weight reduction, improved accuracy and structural integrity, etc. On the other hand, as disadvantages can be mentioned additional costs for technology design, often reduced formability of parts material, uneven plastic flow during drawing and instability of weld line position [1-3].

There are several types of tailored blanks. The major part includes tailorwelded blanks (TWB) prepared by laser welding of particular parts. Specialised manufacturers offer tailor-rolled blanks (TRB) with non-constant thickness for large purchasers. A comparison of both types of preparation sounds

\footnotetext{
1 Autor do korespondencji/corresponding author: Alexander Schrek, Slovak University of Technology, Námestie slobody 17, 81231 Bratislava, Slovakia, e-mail: alexander.schrek@stuba.sk

2 Pavol Švec, Slovak University of Technology, e-mail: pavol.svec@ stuba.sk

3 Veronika Gajdošová, Slovak University of Technology, e-mail: veronika.gajdosova@stuba.sk
} 
generally in favor of the rolling. Such a production is cheaper only for a highvolume production. The thickness change can be oriented only in the direction perpendicular to the rolling direction and it is not possible to achieve a significanlty different stress-strain properties of the blank [1].

High-strength transformation induced plasticity (TRIP) steels, often used for TWBs belong to the steel grades, whose application is possible to obtain desired properties of the drawn parts for car body structure. It has also a positive impact on the weight reduction of components, in some cases up to $20 \%$ with subsequent reduction of fuel consumption. Increased rigidity, strength of the support structure and the ability to absorb energy during a car accident positively influence the safety of cars. The usage of these high-strength steels increases deformation ability in a wide range of temperatures and strain rates. These properties make them suitable for the use in deformation zones, respectively as reinforcements in various parts of cars $[4,5]$.

One of the basic objectives of the research that is being done at the Faculty of Mechanical Engineering of Slovak University of Technology in Bratisla$\mathrm{va}$, is to determine the ductile properties of selected high-strength steels and TWBs, composed of these steels, and to determine the conditions for successful drawing using a tool with relatively simple customised blankholder. The paper presents some results obtained experimentally as well as using a computer simulation when drawing of rectangular boxes from the TRIP 780 TWBs [6].

\section{Experimental procedure}

A forming tool with blankholder for simple drawing of rectangular box was designed and manufactured. The punch was anchored to a bottom bolster connected to the lower base of the PYE 160 press operated with a nominal force $160 \mathrm{kN}$. Transmission pillars, which pass through the bottom bolster, transmit the power to the blankholder created by lower base of the press. The die is located on the upper arm. The drawn part is formed when moving die in relation to static punch. The arm of the press creates the tensile force and combined with the base it creates the blankholder force. The blankholder plate is quasi-elastic and able to transmit uneven pressure on the flange of blank. The pressure is created by transmission pillars with different, adjustable height. The tool has been equipped with the force sensors. There are sensors of local forces transmitted by each pillar at four points of blankholder and sensor of total forming force transmitted by the punch. Figure 1 shows the example of the forming force variation of both the punch and the blankholder forces of particular pillars in the case of non-uniform distribution of the blankholder pressure. The forces variation is based on the height of the product [7, 8]. Figure 2 shows rectangular box created by deep drawing with dimensions of 120 $\mathrm{mm} \times 80 \mathrm{~mm}$ and a height of approximately $40 \mathrm{~mm}$. TWBs were welded from 
two sheets with thicknesses of $1 \mathrm{~mm}$ and $1.2 \mathrm{~mm}$. The weld line was oriented lengthwise, crosswise or diagonally with respect to the larger dimension of the blank. Figure 3 shows the case of the crosswise position.

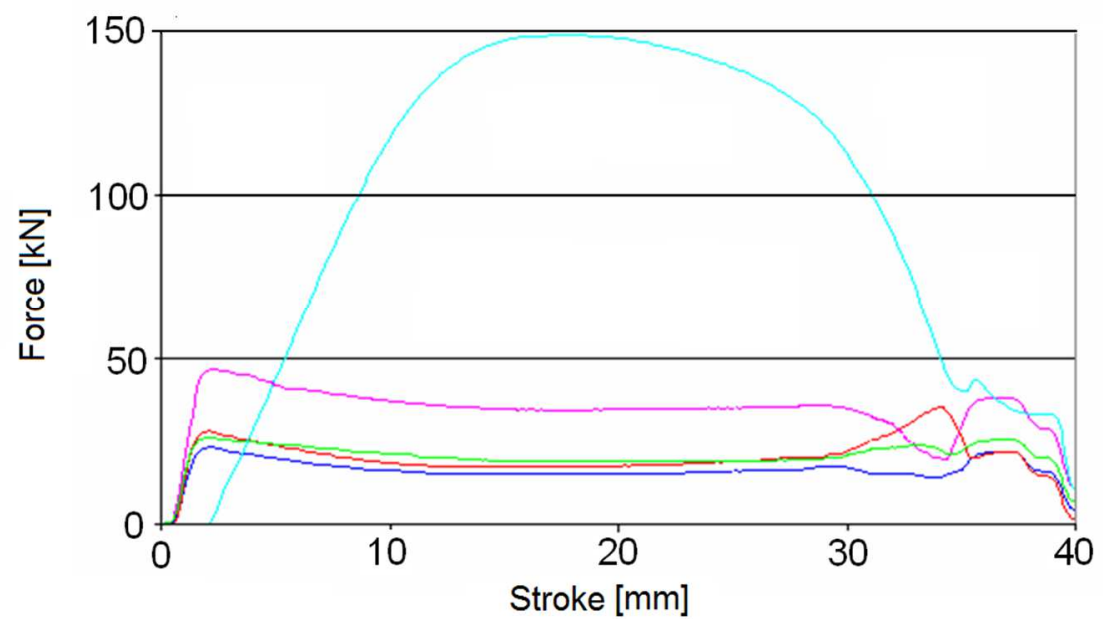

Fig.1 Variation of the forming and blankholder forces during deep drawing with non-uniform distribution of blankholder pressure, mode B: purple line- force on the pillar no. 1, blue lineforce on the pillar no. 2, green line - force on the pillar no. 3, red line - force on the pillar no. 4, azure line - punch force

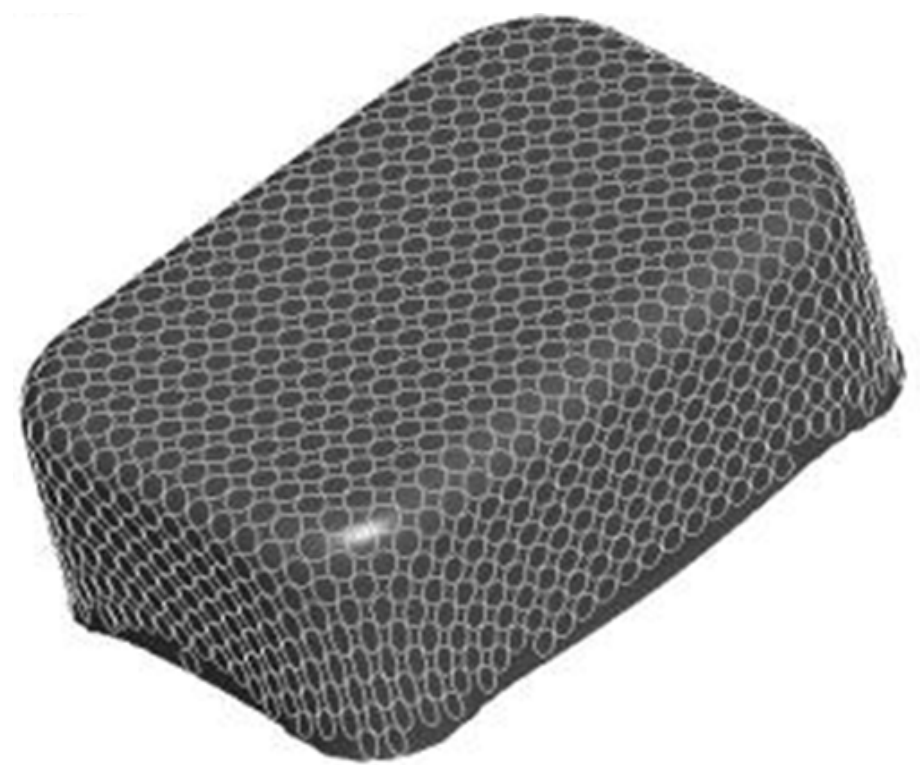

Fig. 2. Drawn part with deformation grid 


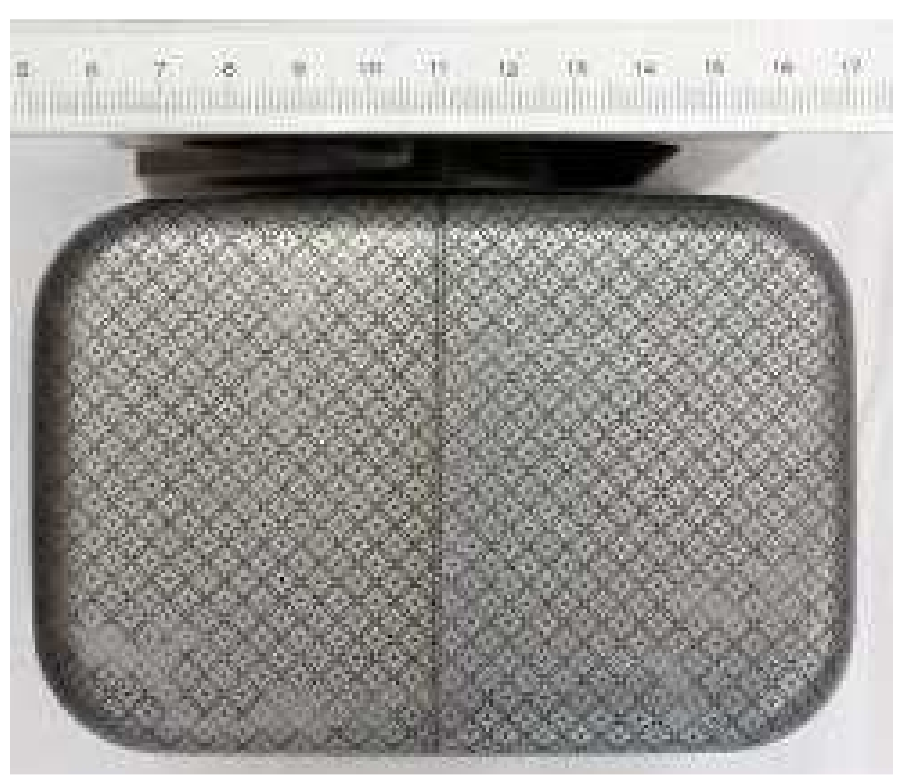

Fig. 3. Bottom of the rectangular box with crosswise oriented weld line

Strain distribution on the surface of the drawn part was evaluated by an optical system based on the deformed grid. All experiments were simultaneously simulated in Dynaform software, using the experimentally determined stress-strain properties. Figure 4 shows the examples of the strain distribution when applying non-uniform pressure on the blank of constant thickness (Fig. 4a) as well as when applying uniform pressure on the TRIP 780 steel blank of non-constant thickness (Fig. 4b). The strain is determined based on the deformation of the grid, that consists of 35 elements with a diameter of $4.75 \mathrm{~mm}$ located along a line through the centre of the blank, upright on the weld line.

Experimentally determined behaviour of strains $\varphi_{1}$ and $\varphi_{2}$ at a blank of constant thickness and when there is non-uniform blankholder pressure with a maximum difference of $10 \%$ (Fig. 4) clearly shows differences in the bottom of created boxes in their symmetrical parts. The material flow in the right part of the bottom with higher blankholder pressure is held back against the left side. The left side of the bottom had a relatively large strain before the transition into the wall of the product. The nature of the strain distribution in the bottom is confirmed by the simulation. Asymmetry of the deformation caused by non-uniform acting of blankholder pressure is more significant when compared to the deformation $\varphi_{1}$ in the walls. Strain on the right side is more intensive and braking zones have also a different character. A difference of behaviour of the deformation $\varphi_{2}$ in right and left wall was confirmed by the simulation. When drawing TWBs with different thicknesses and quasi-uniform pressure distribution, the weld line on the bottom generally moves towards thicker 
material - to the left. The result is an increased plastic flow from the flange of thinner blank part into the die (right side of the figure 4b) [9].

Figure 5 shows experimentally observed and simulated distribution of major and minor strains on the rectangular boxes from TWBs. Two examples of strain distribution for two different blankholder pressure values are mentioned.

a)

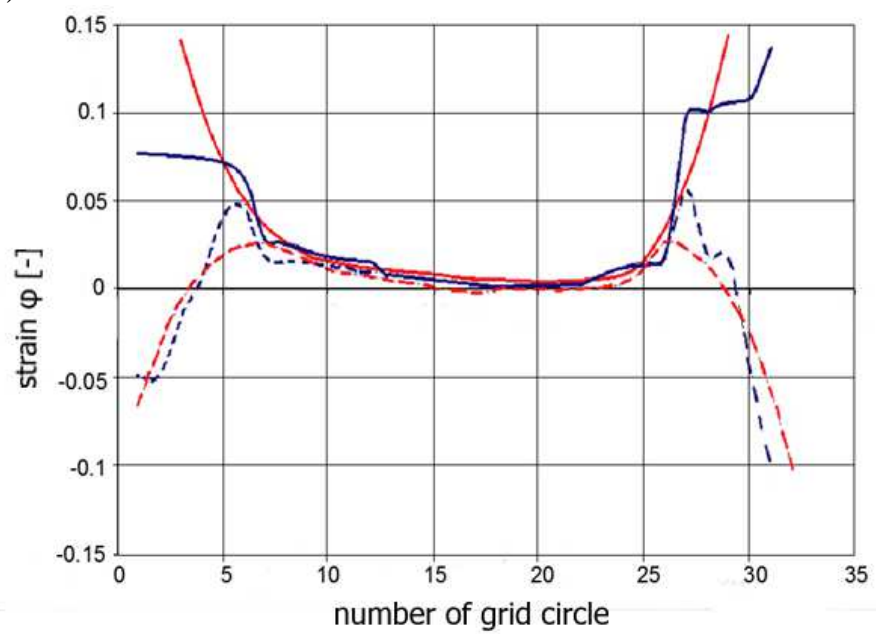

b)

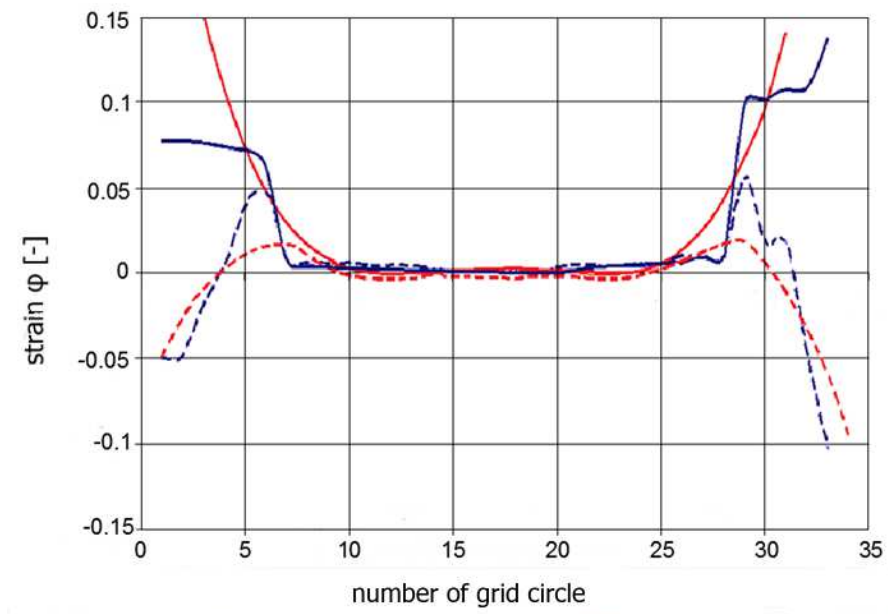

Fig. 4. The strain distribution on the part drawn from TRIP 780 steel vs. number of the elements along the middle line of the deformation grid from left to the right: a - blank with uniform thickness of $1 \mathrm{~mm}$ after deep drawing with non-uniform distribution of blankholder pressure, $\mathrm{b}$ TWB with 1 and $1.2 \mathrm{~mm}$ thicknesses with uniform distribution of blankholder pressure; red line - simulation, blue line- experiment, continuous line - major strain $\varphi_{1}$ along the line in the middle of the box length, dashed line - minor strain $\varphi_{2}$ along the line in the middle of the box length 
The maximum non-uniform pressure difference is $10 \%$ for A regime, and $20 \%$ for B regime. Redistribution of blankholder pressure when drawing TWB with a maximum increase of $10 \%$ on the side of the thinner blank part means a creation of conditions for a relatively uniform plastic flow with virtually no strain of the bottom of the drawn part (Fig. 5a). The strain values in the lower parts of the walls are comparable on the left and right side. An intensive increase in the wall thinning is observed on the upper part of the wall on the right side. The distribution of strain $\varphi_{2}$, determined experimentally and numerically, is almost symmetrical on both sides. An increase in the difference between maximum and minimum blankholder pressure to $20 \%$ (Fig. 5 b) improves the drawn part symmetry. It is confirmed mainly by the simulation of strain distribution. The increase of differences of blankholder pressure causes a greater braking of material flow in the flange and increase of the strain on the part bottom.

Movement and deformation of the weld line were also a subject of the presented research. The clear result of increasing blankholder pressure on the side of the thinner material is braking the movement of the weld interface. The best result was achieved in the case of $20 \%$ difference in the pressure size. The weld line movement is also a function of its length and the initial placement on the blank [9].

\section{Conclusions}

TWBs made of TRIP 780 steel can be successfully drawn while producing geometrically complex products, despite their reduced formability when compared to simple blanks made of mild steel. Controlled non-uniform distribution of the blankholder pressure with quasi-elastic blankholder plate is an effective way to improve the strain distribution on the bottom and walls of the rectangular box and for braking the weld line movement. Correct adjustment of the height of the pillars transmitted the pressure on a blankholder plate allows to create the conditions for the uniform height of the box walls and small strain variations in corresponding parts of the symmetrical product.

Explicit finite element software Dynaform allows reliable simulation of drawing a blank of high-strength steel in the particular circumstances, including the strain distribution in an non-uniform and changing contact conditions in the area of blankholder. The appropriate choice of loaded system model also enables the simulation of the weld line movement, including its deformation and rotation. 
a)

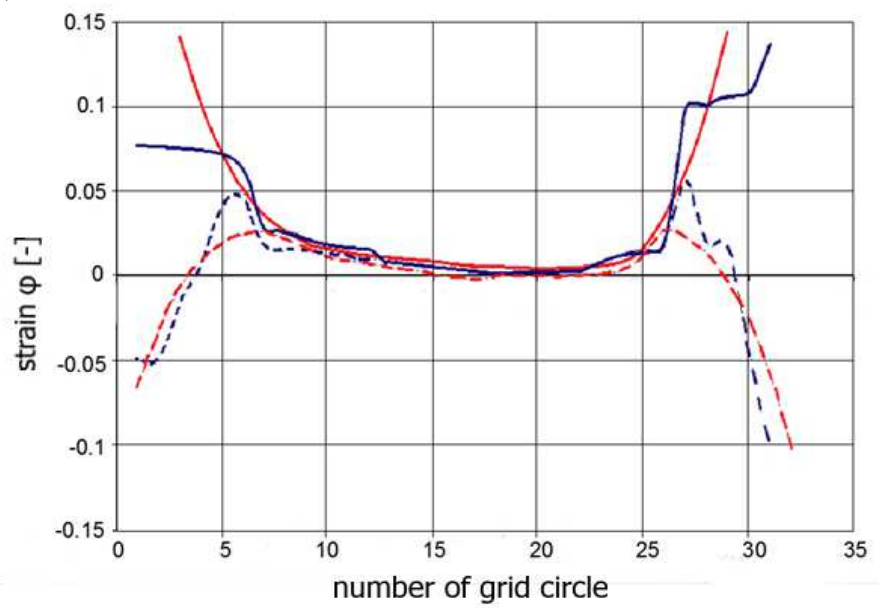

b)

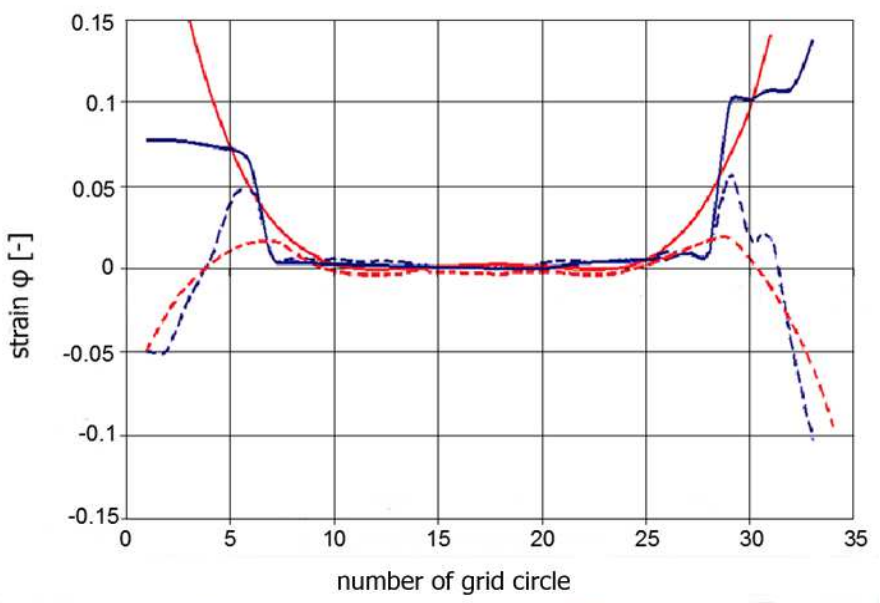

Fig. 5. The strain distribution on the part drawn from TRIP 780 steel vs. number of the elements along the middle line of the deformation grid from left to the right: a - TWB with 1 and $1.2 \mathrm{~mm}$ thicknesses with non-uniform distribution of blankholder pressure ( mode A), b - TWB with 1 and $1.2 \mathrm{~mm}$ thicknesses with non-uniform distribution of blankholder pressure (mode B); red line - simulation, blue line - experiment, continuous line - major strain $\varphi_{1}$ along the line in the middle of the box length, dashed line - minor strain $\varphi_{2}$ along the line in the middle of the box length,

\section{Acknowledgement}

This work was supported by the Slovak Research and Development Agency under the contract no. APVV-0281-12 


\section{References}

[1] Kinsey L.B., Wu X.: Tailor-welded blanks for advanced manufacturing, Woodhead, Cambridge 2011.

[2] Evin E., Tomáš M.: Comparison of deformation properties of steel sheets for car body parts, Procedia Eng., 48 (2012) 115-122.

[3] Frącz W., Stachowicz F., Trzepieciński T., Pieja T.: Forming limit of the heat resistant AMS 5599 sheet metal, Hutnik, 81 (2014) 442-445 (in Polish).

[4] Kestens L., Petrov R., Hubert Y.: Orientation selective transformation during intercritical annealing of cold rolled TRIP steel, Int. Conf. TRIP-Aided High Strength Ferrous Alloys, Ghent 2002, pp. 215-220.

[5] Slota J., Jurčišin M., Spišák E.: Experimental and numerical analysis of local mechanical properties of drawn part, Key Eng. Mat., 586 (2014) 245-248.

[6] Kostka P., Žitňanský P., Čekan P., Schrek A.: Numerical simulation of deep drawing of dual-phase steel, Forming the Future Innovations in Sheet Metal Forming, IDDRG 2007 Conf, Proc., Györ 2007, pp. 55-58.

[7] Schrek A., Činák M., Žitňanský P.: Experimental laboratory tooling for deep drawing process, Faculty of Mechanical Engineering, STU Bratislava. Sci. Proc. 2011, pp. 23-28.

[8] Choi Y., et al.: Investigation of welde line movements for the deep drawing process of tailored welded blanks, J. Mater. Proc. Technol. 108 (2000) 1-7.

[9] Žitňanský P., Kostka P., Schrek A.: Simulation of high strength steel deep drawing using tailored blanks, Zborník vedeckých prác Strojníckej fakulty STU, Bratislava 2010.

\section{GLEBOKIE TŁOCZENIE SPAWANYCH BLACH WYKONANYCH ZE STALI WYSOKOWYTRZYMALEJ}

\section{Streszczenie}

W artykule przedstawiono badania porównawcze oceny głębokiego tłoczenia prostokątnej wytłoczki, składającej się z dwóch części o różnej grubości, wykonanej z blachy przeznaczonej do spawania. Wsad jest wykonany z blachy wysokowytrzymałej umacnianej przez przemianę fazową, a linia spawania znajduje się w środku wsadu, w momencie rozpoczęcia procesu głębokiego tłoczenia. Badania koncentrują się na analizie przemieszczenia linii spawania $\mathrm{w}$ warunkach quasi- równomiernego i nierównomiernego rozkładu ciśnienia dociskacza, które jest przyłożone do kołnierza półwyrobu. Celem badań jest minimalizacja przemieszczenia linia spawania oraz poprawa odkształcalności blachy przeznaczonej do spawania.

Słowa kluczowe: głębokie tłoczenie, blacha przeznaczona do spawania, symulacja, linia spawania

DOI: $10.7862 / \mathrm{rm} .2016 .17$

Otrzymano/received: 31.05.2016 r.

Zaakceptowano/accepted: $14.09 .2016 \mathrm{r}$. 